\title{
The Use of Cloud Point Extraction and Hydride Generation for Improving the Sb and Se Limits of Detection in ICP OES
}

\author{
Fernanda dos Santos Depoi and Dirce Pozebon* \\ Instituto de Química, Universidade Federal do Rio Grande do Sul, \\ Av. Bento Gonçalves 9500, 91501-970 Porto Alegre-RS, Brazil
}

\begin{abstract}
O presente estudo trata da aplicação da extração no ponto nuvem (CPE) e geração de hidretos (HG) para a determinação de Sb e Se por espectrometria de emissão óptica com plasma indutivamente acoplado (ICP OES). O complexante utilizado foi o dietilditiofosfato de amônio (DDTP), enquanto que Triton X-114 foi usado como surfactante para a formação das micelas. As condições para a pré-concentração de $\mathrm{Sb}(\mathrm{III})$ e $\mathrm{Se}(\mathrm{IV})$, redução de $\mathrm{Se}(\mathrm{VI})$ e $\mathrm{Sb}(\mathrm{V})$, geração dos respectivos hidretos e interferências foram avaliadas e discutidas. O desempenho da HG foi comparado com o da nebulização pneumática $(\mathrm{PN})$ para introduzir a fase rica em surfactante no plasma. Mediante aplicação da HG, os limites de detecção obtidos para $\mathrm{Se}(\mathrm{IV}$ ) e $\mathrm{Sb}$ (III) foram 0,05 e $0,08 \mu \mathrm{g} \mathrm{L}^{-1}$, respectivamente. No caso da aplicação da PN, os limites de detecção do Se(IV) e $\mathrm{Sb}$ (III) foram 0,90 e 2,90 $\mu \mathrm{g} \mathrm{\textrm {L } ^ { - 1 }}$, respectivamente. Foram analisadas amostras de nozes e castanha do Pará, água e vinho branco. O Se(IV) foi quantificado na castanha do Pará, enquanto que o $\mathrm{Sb}$ (III) foi quantificado em água de estuário, água de mar e água mineral embalada em garrafa feita de politereftalato de etileno (PET).
\end{abstract}

This study deals with the application of cloud point extraction (CPE) and hydride generation (HG) for determination of $\mathrm{Sb}$ and Se using inductively coupled plasma optical emission spectrometry (ICP OES). The complexing agent was ammonium diethylditiophosphate (DDTP), whereas Triton X-114 was used as surfactant for the formation of micelles. Conditions for $\mathrm{Sb}(\mathrm{III})$ and $\mathrm{Se}(\mathrm{IV})$ preconcentration, reduction of $\mathrm{Se}(\mathrm{VI})$ and $\mathrm{Sb}(\mathrm{V})$, hydrides generation and interferences were discussed. The performance of $\mathrm{HG}$ was compared with pneumatic nebulization (PN) for introducing the surfactant-rich phase into the plasma. Upon application of HG, the limits of detection (LODs) for $\mathrm{Se}(\mathrm{IV})$ and $\mathrm{Sb}(\mathrm{III})$ were 0.05 and $0.08 \mu \mathrm{g} \mathrm{L}^{-1}$, respectively. Limits of detection using PN were 0.90 and $2.90 \mathrm{ug} \mathrm{L}^{-1}$ for $\mathrm{Se}(\mathrm{IV})$ and $\mathrm{Sb}(\mathrm{III})$, respectively. Samples of nuts, water and white wine were analyzed. Selenium(IV) was quantified in Brazil nut whereas $\mathrm{Sb}$ (III) was in estuarine water, seawater and mineral water stored in polyethylene terephthalate (PET) bottle.

Keywords: Sb and Se, cloud point extraction, ICP OES, hydride generation, pneumatic nebulization

\section{Introduction}

Selenium is a natural component of enzymes and is fundamental in several metabolic processes. Deficit of Se may promote cardiac diseases, hypothyroidism and weakness of the immunologic system. However, Se is toxic when present in elevated concentrations, which is dependent on the Se species. ${ }^{1}$

Antimony is a potentially toxic element, without any documented biological function. It is a trace element, which

*e-mail: dircepoz@iq.ufrgs.br is being introduced into our surroundings in increasing quantities. Modern applications of Sb have increased dramatically during the last few decades and nowadays $\mathrm{Sb}$ is used in a broad range of products, such as rubber and plastics, packaging materials, bactericides, fungicides, etc. ${ }^{2}$ Thus, humans and other biological systems are subjected to an ever increasing antimony exposure.

Direct determination of $\mathrm{Sb}$ and $\mathrm{Se}$ at low concentrations is commonly difficult by using spectroscopic techniques such as AAS (atomic absorption spectrometry) and ICP OES (inductively coupled plasma optical emission spectrometry) owing to the lack of sensitivity. The use of 
hydride generation (HG) can improve the sensitivity by increasing the efficiency of analyte transport, by helping to separate the analyte from the matrix, and by reducing associated non spectroscopic interference effects. The use of $\mathrm{HG}$ is also suitable for high sensitive techniques such as ICP-MS (inductively coupled plasma mass spectrometry) due to matrix separation provided by HG. It is worth pointing out that the limit of detection (LOD) for Se directly measured by ICP-MS is often relatively high due to polyatomic interferences.

Antimony and Se species react with tetrahydroborate in acidic medium to form volatile hydrides, which are subsequently detected. However, the formation of hydrides is dependent on the oxidation state of the element. For example, Se(IV) forms hydrides whereas $\mathrm{Se}(\mathrm{VI})$ does not. Thus, $\mathrm{Se}(\mathrm{VI})$ must be reduced to $\mathrm{Se}(\mathrm{IV})$ that can be measured by using HG and a specific detector.

When HG is used there is an improvement in sensitivity by two orders of magnitude relative to pneumatic nebulization (PN). ${ }^{3}$ However, depending on the type of sample analyzed, analyte preconcentration may be necessary for its detection by ICP OES, even using HG.

Cloud point extraction (CPE) has been applied for $\mathrm{Sb}$ and $\mathrm{Se}$ separation/preconcentration in the last decade. ${ }^{4-15}$ Cloud point extraction is based on micelles formation and subsequent separation. Micellar aqueous solution is produced by addition of surfactant whose concentration in the solution must ensure the formation of micelle aggregates; the final surfactant concentration must exceed the critical micelle concentration (CMC). Once the surfactant concentration exceeds CMC, the aqueous micellar solution can separate into two isotropic phases: a surfactant-rich phase of small volume and a surfactant-poor phase of much higher volume (aqueous). Any component that binds to the micellar aggregate in solution can be extracted from the original solution and, therefore, be concentrated in the surfactant-rich phase. In the case of hydrophilic inorganic species, complexing agents are commonly used for producing hydrophobic species that are extracted into the micelles, thereby in a small volume that is separated. In the case of using ICP OES for analyte detection, the viscosity and the organic content of the surfactant-rich phase affect the plasma performance and stability. Therefore, appropriate sample introduction systems and free-clogging nebulizer are required.

Triton $\mathrm{x}-114$ has been used as surfactant whereas 2,3-diaminonaphtalene (DAN), ${ }^{4}$ ammonium pyrrolidine dithiocarbamate (APDC), ${ }^{5,6,10,15}$ diethyldithiocarbamate (DDTC), ${ }^{7}$ 3,3'-diaminobenzidine (DAB), ${ }^{8}$ o-phenylenediamine ${ }^{9}$ and N-benzoyl$\mathrm{N}$-phenylhydroxylamine (BPHA) ${ }^{13}$ have been used as complexants. These complexants react specifically with $\mathrm{Se}(\mathrm{IV})$ and/or $\mathrm{Sb}(\mathrm{III})$. Total $\mathrm{Se}$ and total $\mathrm{Sb}$ have been determined after $\mathrm{Se}(\mathrm{VI})$ and $\mathrm{Sb}(\mathrm{V})$ were reduced by L-cysteine, ${ }^{6,10,13,14}$ or $\mathrm{Se}(\mathrm{VI})$ reduced to $\mathrm{Se}(\mathrm{IV})$ by microwave heating of solution in $4 \mathrm{~mol} \mathrm{~L}^{-1} \mathrm{HCl}^{8}{ }^{8}$ Concentrations of $\mathrm{Se}(\mathrm{VI})$ and $\mathrm{Sb}(\mathrm{V})$ were obtained by respectively subtracting $\mathrm{Se}(\mathrm{IV})$ and $\mathrm{Sb}$ (III) from the total Se and the total Sb.

Cloud point extraction has been applied for speciation of organic and inorganic Se in vitamin tablets prior Se determination by fluorometry; ${ }^{4}$ total Se determination in acid digests of scalp hair and blood serum by electrothermal atomic absorption spectrometry (ETAAS); 5 speciation of inorganic Se in water followed by detection using electrothermal vaporization inductively coupled plasma mass spectrometry (ETV-ICP-MS); 6 speciation of Se(IV) and Sb(III) in water samples using ETV-ICP-MS for detection; ${ }^{7}$ preconcentration of Se(IV) in water samples and total Se in biological samples followed by detection using ETAAS, ${ }^{8,9}$ speciation of inorganic $\mathrm{Sb}$ in leaching solutions of different food packaging materials prior detection by ETAAS; ${ }^{10} \mathrm{Sb}$ separation/preconcentration in seawater, anti-leishmania drug (glucantime), and human serum using spectrophotometric detection; ${ }^{11}$ separation/preconcentration of $\mathrm{Sb}$ (III) in water prior detection by ETAAS; ${ }^{12}$ preconcentration of $\mathrm{Sb}$ (III) in artificial seawater and wastewater with detection by flame atomic absorption spectrometry (FAAS) $;^{13}$ inorganic $\mathrm{Sb}$ species determination by combining on-line CPE with electrothermal vaporization inductively coupled plasma optical emission spectrometry (ETV-ICP OES); ${ }^{14}$ and determination of $\mathrm{Sb}(\mathrm{III})$ in natural water prior detection by ETAAS..$^{15}$

Hydride generation in conjunction with CPE and ICP OES has not been investigated for determining $\mathrm{Sb}$ and Se so far, leading us to investigate and compare the HG performance for $\mathrm{Sb}$ and $\mathrm{Se}$ in the surfactant-rich phase following detection by ICP OES. The main purpose is to improve the LODs of Se and Sb in ICP OES. The HG performance is compared with those of conventional pneumatic nebulization (PN) and nebulization/aerosol desolvation, seeking the sample introduction system that provides the best sensitivity.

\section{Experimental}

\section{Instrumentation}

An Optima 2000 DV-ICP OES spectrometer (PerkinElmer, Norwalk, CT, USA) was used. Argon (purity of $99.998 \%$ from White Martins/Praxair) was used as plasma gas and auxiliary gas, meanwhile nitrogen with purity of $99.996 \%$ (White Martins/Praxair) was used 
as purging gas. The main instrumental parameters are summarized in Table 1. These parameters were employed following previous works. ${ }^{16,17}$

A homemade HG system was hyphenated with ICP OES and used for Se and $\mathrm{Sb}$ determination. This system is described elsewhere. ${ }^{16}$ It consists basically of a confluence and a gas liquid separator; solutions are transported and mixed using the peristaltic pump of the ICP OES. The flow rates of sample, $\mathrm{HCl}$ and $\mathrm{NaBH}_{4}$ solutions were $1.3,1.8$ and $1.3 \mathrm{~mL} \mathrm{~min}^{-1}$, respectively. The pneumatic nebulizer used (GemCone) is considered freeclogging and suitable for viscous solutions or solutions with high content of dissolved solids. An APEX-Q system (ESI, USA) with aerosol desolvation was also used. In this system, solutions were aspirated through a PFA concentric nebulizer fitted into a cyclonic spray chamber that was heated at $140{ }^{\circ} \mathrm{C}$ and then transported to a Peltier-cooled multipass condenser where the temperature was set as $2{ }^{\circ} \mathrm{C}$. Partial solvent removal occurs in this system and sample transport efficiency is about $30 \%$.

A heating block (TE-007D Tecnal, Piracicaba, SP, Brazil) and a microwave oven Multiwave 3000 (Anton Paar, Graz, Austria) were used for sample decomposition. A water bath with temperature control was used as a source of heating and assists CPE while a centrifuge was used for separation of the aqueous and surfactant-rich phases.

\section{Reagents and solutions}

All chemicals were of analytical-grade. Water purified (resistivity of $18.2 \mathrm{M} \Omega \mathrm{cm}$ ) in a Milli-Q system (Millipore, Bedford, MA, USA) was used to prepare all reagents, solutions and samples. Nitric acid (65\% in mass), $\mathrm{HCl}$ (37\% in mass), $\mathrm{H}_{2} \mathrm{O}_{2}\left(30 \%\right.$ in mass), methanol $\left(\mathrm{CH}_{3} \mathrm{OH}\right)$ and ethanol $\left(\mathrm{CH}_{3} \mathrm{CH}_{2} \mathrm{OH}\right)$, all from Merck (Darmstadt, Germany) were used. The purchased $\mathrm{HNO}_{3}, \mathrm{HCl}$ and
$\mathrm{CH}_{3} \mathrm{OH}$ were further purified by sub-boiling distillation using a Milestone duo PUR 2.01E system (Sorisole, Italy). Sodium tetrahydroborate $\left(\mathrm{NaBH}_{4}\right.$, Vetec, RJ, Brazil) prepared in $\mathrm{NaOH} 0.05 \%(\mathrm{~m} / \mathrm{v})$ was used for $\mathrm{Se}(\mathrm{IV})$ and $\mathrm{Sb}$ (III) hydrides generation. DDTP $\left[\left(\mathrm{C}_{2} \mathrm{H}_{5} \mathrm{O}\right)_{2} \mathrm{P}(\mathrm{S}) \mathrm{SNH}_{4}\right]$ from Sigma-Aldrich (USA) and Triton X-114 from Sigma-Aldrich (USA) were used for $\mathrm{Se}(\mathrm{IV})$ and $\mathrm{Sb}(\mathrm{III})$ preconcentration. A $5.0 \%(\mathrm{~m} / \mathrm{v})$ DDTP stock solution was prepared by dissolving the reagent in water. A $5.0 \%(\mathrm{~m} / \mathrm{v})$ Triton X-114 stock solution was prepared by weighing $2.5 \mathrm{~g}$ of the reagent in a polypropylene vial followed by addition of $50 \mathrm{~mL}$ of water. Antifoam Y-30 from Sigma-Aldrich (USA) was used to avoid foam production in the gas/liquid separator of the HG system. Potassium iodine (KI), ascorbic acid $\left(\mathrm{C}_{6} \mathrm{H}_{8} \mathrm{O}_{6}\right)$, and L-cysteine $\mathrm{C}_{3} \mathrm{H}_{7} \mathrm{NO}_{2} \mathrm{~S} . \mathrm{HCl}$ from Sigma-Aldrich (USA) were used for $\mathrm{Se}(\mathrm{VI})$ and $\mathrm{Sb}(\mathrm{V})$ reduction. Calibration solutions of $\mathrm{Se}$ and $\mathrm{Sb}$ were prepared in $0.14 \mathrm{~mol} \mathrm{~L}^{-1} \mathrm{HNO}_{3}$ by serial dilution of $\mathrm{Sb}$ stock solution or salts of selenium (Table 2). The calibration solutions were also submitted to CPE in the same way that samples.

All vials and glassware used for samples preparation or storage of the calibration solutions were previously decontaminated by contact with $10 \%(\mathrm{v} / \mathrm{v}) \mathrm{HNO}_{3}$ for $48 \mathrm{~h}$. Then, the vials were washed and rinsed with deionized water. The PTFE flasks used for the decomposition of the samples were decontaminated by adding $3 \mathrm{~mL}$ of $\mathrm{HNO}_{3}$ and heating at $160{ }^{\circ} \mathrm{C}$ for $4 \mathrm{~h}$ in a metallic block.

\section{Samples and sample preparation}

The following non certified samples were analyzed: coconut water, white wine (Chardonnay), mineral water, nuts (Brazil nut, walnuts, sweet almond and hazelnuts), estuarine water (Guaíba, Rio Grande do Sul State, Brazil), seawater (from nearshore in Rio Grande do Sul) and tap water (collected in our own laboratory). Nut samples,

Table 1. Instrumental operating conditions for ICP OES with hydride generation (HG) or pneumatic nebulization (PN)

\begin{tabular}{lcc}
\hline \multirow{2}{*}{ Parameter } & \multicolumn{2}{c}{ Sample introduction } \\
\hline Plasma power / & HG & PN \\
Plasma gas flow rate / $\left(\mathrm{L} \mathrm{min}^{-1}\right)$ & 1500 & 1500 \\
Auxiliary gas flow rate / $\left(\mathrm{L} \mathrm{min}^{-1}\right)$ & 15 & 15 \\
Nebulizer or carrier gas flow rate / $\left(\mathrm{L} \mathrm{min}^{-1}\right)$ & 0.2 & 0.2 \\
Spray chamber & 0.6 & 0.6 \\
Nebulizer & - & umbafled cyclonic \\
Spectral line / $\mathrm{nm}$ & - & GemCone or APEX-Q \\
Plasma view & Sb: 206.836 & Se: 203.985 \\
\hline
\end{tabular}


Table 2. Stock and calibration solutions of $\mathrm{Sb}$ and $\mathrm{Se}$

\begin{tabular}{|c|c|c|c|}
\hline Stock solution or salt & $\begin{array}{c}\text { Concentration range of } \\
\text { calibration curve / } \\
\left(\mu \mathrm{g} \mathrm{L}^{-1}\right) \text { with CPE }\end{array}$ & $\begin{array}{c}\text { Concentration range of } \\
\text { calibration curve / } \\
\left(\mu \mathrm{g} \mathrm{L}^{-1}\right) \text { without } \mathrm{CPE}\end{array}$ & Sample introduction mode \\
\hline \multirow[t]{2}{*}{ Se $\left(100 \mathrm{mg} \mathrm{L}^{-1}\right)$ from $\mathrm{Na}_{2} \mathrm{SeO}_{3}$, Merck } & $5.0-20$ & $20-60$ & $\mathrm{PN}$ \\
\hline & $1.0-10$ & $5.0-25$ & $\mathrm{HG}$ \\
\hline $\mathrm{Se}\left(100 \mathrm{mg} \mathrm{L}^{-1}\right)$ from $\mathrm{Na}_{2} \mathrm{SeO}_{4}$, Merck & - & $1.0-20$ & $\mathrm{HG}$ \\
\hline \multirow[t]{3}{*}{ Sb (1000 mg L $\left.{ }^{-1}\right)$, Merck } & $10-50$ & $20-100$ & PN/DES \\
\hline & $1.0-5.0$ & $5.0-25$ & $\mathrm{HG}$ \\
\hline & $10-50$ & $20-100$ & $\mathrm{PN}$ \\
\hline
\end{tabular}

PN: pneumatic nebulization; PN/DES: pneumatic nebulization/aerossol desolvation; HG: hydride generation.

coconut water and white wine were purchased in local shops. Certified dogfish liver (DOLT-4) and certified river water (SLRS-5) both from the National Research Council of Canada (NRCC, Ottawa, Canada) were analyzed.

The estuarine water was filtered and acidified by adding 1 drop of concentrated $\mathrm{HNO}_{3}$ to $250 \mathrm{~mL}$ of sample, filtered and analyzed immediately. The other liquid samples (tap water, seawater, river water, mineral water coconut water and white wine) were analyzed without initial preparation; they were merely diluted by adding different volumes of $\mathrm{HCl}$ or $\mathrm{HNO}_{3}$ solutions and the required reagents. Procedure 2 (see below) was used for decomposition of the certified dogfish liver (DOLT-4).

Nut samples were initially crushed in a blender. Then, the lipid fraction was extracted from $2 \mathrm{~g}$ of the crushed sample using a solution composed of $3.4 \mathrm{~mL}$ of methanol and $6.6 \mathrm{~mL}$ of chloroform. The obtained mixture was sonicated in an ultrasonic bath for $30 \mathrm{~min}$ and then filtered through quantitative filter paper. The solid residue (non-lipid fraction) was washed several times with water and left drying at room temperature. This extraction procedure was based on the work of Welna et al. ${ }^{18}$ Aliquots of the resulting solid were decomposed according to procedures 1 and 2 as follows.

\section{Procedure 1}

A mass of $100 \mathrm{mg}$ of sample was weighted and placed in PTFE flask to which $1.0 \mathrm{~mL}$ of $\mathrm{HNO}_{3}$ and $1.0 \mathrm{~mL}$ of $\mathrm{H}_{2} \mathrm{O}_{2}$ were added and the mixture left in contact for $12 \mathrm{~h}$. Afterwards, the flask was closed with screw cap and the content heated in a metallic block for $1 \mathrm{~h}$ at $100^{\circ} \mathrm{C}$ followed by $4 \mathrm{~h}$ at $150{ }^{\circ} \mathrm{C}$. After cooling to room temperature, the flask was opened, the resulting solution transferred to graduated polypropylene vial and the volume completed to $25 \mathrm{~mL}$ by adding water.

\section{Procedure 2}

A mass of $100 \mathrm{mg}$ of sample was weighted and transferred to the flask of the microwave oven. Then,
$1 \mathrm{~mL}$ of $\mathrm{HNO}_{3}$ and $1 \mathrm{~mL}$ of $\mathrm{H}_{2} \mathrm{O}_{2}$ were added and the mixture allowed standing for $1 \mathrm{~h}$. Subsequently, the flask was closed and the mixture heated at $220{ }^{\circ} \mathrm{C}$ in the microwave oven; for $3 \mathrm{~min}$ at $300 \mathrm{~W}, 1 \mathrm{~min}$ at $0 \mathrm{~W}, 6 \mathrm{~min}$ at $500 \mathrm{~W}$ and $5 \mathrm{~min}$ at $650 \mathrm{~W}$, followed by cooling for $20 \mathrm{~min}$. The obtained solution was transferred to graduated polypropylene vial whose volume was made up to $25 \mathrm{~mL}$ by adding water. The solutions obtained according to procedures 1 and 2 were used for Se determination.

When recovery tests were carried out for dried sample it was spiked with the analyte before being submitted to the decomposition procedure.

\section{Cloud point extraction procedure}

Aliquots of sample solution ranging from 1 to $7 \mathrm{~mL}$ were transferred to graduated polypropylene vials. Subsequently, DDTP and Triton X-114 were added and the volume completed to $14 \mathrm{~mL}$ by adding water and/or $\mathrm{HCl}$ solution (Table 3). The mixture was heated in a water bath to accelerate the separation of phases, centrifuged at $3200 \mathrm{rpm}$ for $10 \mathrm{~min}$ and then cooled in an ice bath for $10 \mathrm{~min}$. The surfactant-poor phase was separated by inverting the vial, whereas the residual solution was removed by using a

Table 3. Conditions and reagent concentrations evaluated for $\mathrm{Sb}$ and $\mathrm{Se}$ preconcentrations using CPE

\begin{tabular}{lcc}
\hline \multirow{2}{*}{ Condition/Reagent } & \multicolumn{2}{c}{ Element } \\
\cline { 2 - 3 } Preconcentration medium & $\mathrm{HCl}$ & $\mathrm{Se}$ \\
$\mathrm{HCl} /\left(\mathrm{mol} \mathrm{L}^{-1}\right)$ & $0.01-1.0$ & $\mathrm{HCl}$ \\
$\mathrm{DDTP} / \%, \mathrm{~m} / \mathrm{v}$ & $0.05-1.0$ & $0.0-1.0$ \\
Triton X-114 / $\%, \mathrm{~m} / \mathrm{v}$ & $0.05-0.30$ & $0.01-0.3$ \\
Temperature / ${ }^{\circ} \mathrm{C}$ & 50 & $0.05-0.30$ \\
$\mathrm{Heating}$ time $/ \mathrm{min}$ & 20 & 50 \\
$\mathrm{HCl}$ for $\mathrm{HG} /\left(\mathrm{mol} \mathrm{L}{ }^{-1}\right)$ & $0.1-4.0$ & 20 \\
$\mathrm{NaBH}_{4} / \%, \mathrm{~m} / \mathrm{v}$ & $0.1-0.5$ & $0.05-1.5$ \\
\hline
\end{tabular}


Pasteur pipette. The final volume of the surfactant rich phase ranged from 50 to $250 \mu \mathrm{L}$. The surfactant-rich phase was diluted by adding $100 \mu \mathrm{L}$ of methanol followed by addition of $1.0 \mathrm{~mL}$ of $0.1 \mathrm{~mol} \mathrm{~L}^{-1} \mathrm{HCl}$. The surfactant-rich phase has to be diluted due to its high viscosity and/or foam production into the gas liquid separator. ${ }^{16,17}$

The concentrations of the reagents, dilution of the surfactant rich phase and conditions evaluated are summarized in Table 3.

\section{Results and Discussion}

\section{Selenium}

The influence of $\mathrm{HCl}$ and DDTP concentrations on $\mathrm{Se}$ preconcentration was initially evaluated. It was observed that the surfactant-rich phase diluted with methanol caused spectral interference; vapor of methanol was transported to the ICP even by using HG. The presence of an intense peak and bandwidth was highlighted, originated from the emission of C (193.09 nm) and NO (198.05 nm), increasing the background signal and overlapping the signal of the $196.026 \mathrm{~nm} \mathrm{Se}$ emission line. As a consequence, the prominent $196.026 \mathrm{~nm} \mathrm{Se}$ emission line could not be monitored for Se determination. The $203.985 \mathrm{~nm}$ Se line was then selected.

A solution of $\mathrm{Se}(\mathrm{IV})$ was used to evaluate preconcentration since selenium hydride is only generated from this specie. The influence of $\mathrm{HCl}$ concentration is shown in Figure 1a in which one can see that the Se signal decreases with the increase of acid concentration. The reason for the Se signal decrease might be the salting-out effect promoted by chloride ions. ${ }^{19}$ Complex formation

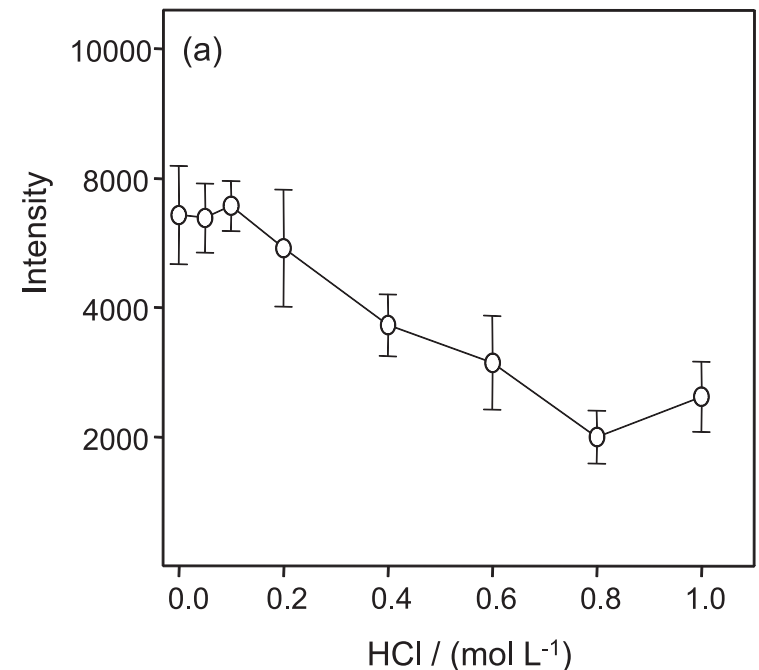

between Se(IV) and DDTP is more effective in presence of low concentration of the ligand, as shown in Figure 1b. This behavior with respect to the DDTP concentration was also observed when SPE (solid phase extraction) was used for on-line preconcentration of Se(IV). ${ }^{20}$

The concentration of Triton X-114 investigated ranged from 0.05 to $0.30 \%(\mathrm{~m} / \mathrm{v})$. It was not possible to evaluate higher concentrations of the surfactant due to foam production in the gas-liquid separator, which caused huge effervescence in the HG system, leading to extinction of the plasma. The highest Se signal was observed for $0.30 \%(\mathrm{~m} / \mathrm{v})$ Triton X-114. However, due to production of foam and the long time necessary for cleaning the gas-liquid separator when using $0.30 \%$ (m/v) Triton X-114, the surfactant concentration was fixed in $0.20 \%(\mathrm{~m} / \mathrm{v})$. The amount of methanol added to the surfactant rich phase was $100 \mu \mathrm{L}$, chosen according to previous works. ${ }^{16,17}$

Regarding to $\mathrm{NaBH}_{4}$ and $\mathrm{HCl}$ solutions used for hydride generation, it was observed that the concentration of the former should be at least $0.50 \%(\mathrm{~m} / \mathrm{v})$ whereas that of $\mathrm{HCl}$ should not exceed $0.1 \mathrm{~mol} \mathrm{~L}^{1}$. The conditions established for $\mathrm{Se}(\mathrm{IV})$ preconcentration/determination is further summarized.

\section{Figures of merit}

The employment of PN for introducing the surfactant rich-phase in the ICP was also investigated and compared. Table 4 shows LODs, EF (enrichment factor), slope and linear correlation coefficient of the calibration curves, obtained using both HG and PN. The LOD values were calculated according to IUPAC (International Union of Pure and Applied Chemistry) recommendation. LOD was

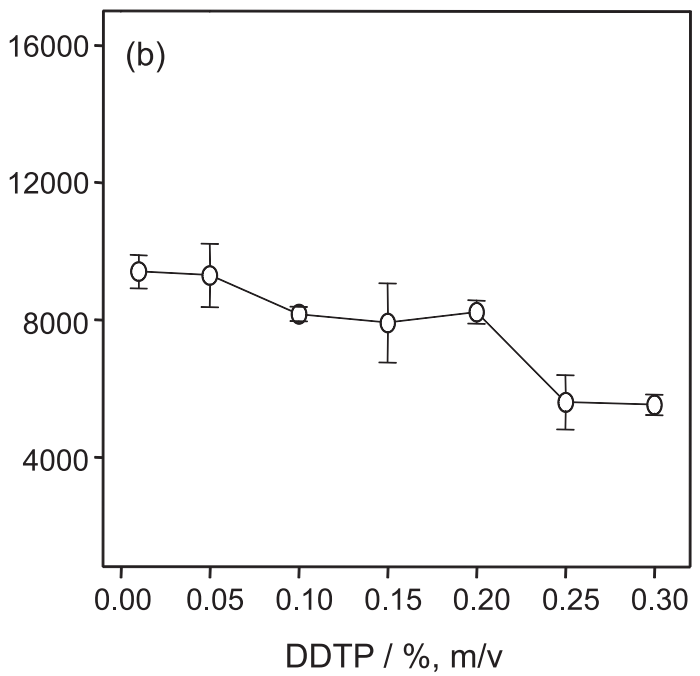

Figure 1. Influence of $\mathrm{HCl}$ and DDTP concentrations on $\mathrm{Se}(\mathrm{IV})$ preconcentration by $\mathrm{CPE}$ prior to determination by $\mathrm{HG}$ and ICP OES; a solution containing $25 \mu \mathrm{g} \mathrm{L} \mathrm{L}^{-1}$ of $\mathrm{Se}(\mathrm{IV})$ was used. Conditions: $0.15 \%(\mathrm{~m} / \mathrm{v})$ DDTP and $0.10 \%(\mathrm{~m} / \mathrm{v})$ Triton X-114 in (a); $0.1 \mathrm{~mol} \mathrm{~L}{ }^{-1} \mathrm{HCl}$ and $0.10 \%$ (m/v) Triton X-114 in (b) $; \mathrm{n}=3$. 
Table 4. Comparison of pneumatic nebulization (PN) and hydride generation (HG) performances for Se(IV) determination using ICP OES after preconcentration by CPE

\begin{tabular}{|c|c|c|c|c|}
\hline \multirow{2}{*}{ Parameter } & \multicolumn{2}{|c|}{ PN } & \multicolumn{2}{|c|}{ HG } \\
\hline & Without CPE & With CPE & Without CPE & With CPE \\
\hline $\mathrm{LOD} /\left(\mu \mathrm{g} \mathrm{L}^{-1}\right)$ & 13.0 & 1.80 & 1.70 & 0.10 \\
\hline $\mathrm{LOD}^{\mathrm{a}} /\left(\mu \mathrm{g} \mathrm{g}^{-1}\right)$ & 6.50 & 0.90 & 0.85 & 0.05 \\
\hline Slope of calibration curve & 2.40 & 106 & 155 & 1158 \\
\hline $\mathrm{EF}$ & - & 44 & - & 8 \\
\hline Linear correlation coeficient of calibration curve & 0.9995 & 0.9985 & 0.9995 & 0.9980 \\
\hline
\end{tabular}

${ }^{\mathrm{a}} 100 \mathrm{mg}$ of sample in $25 \mathrm{~mL}$ further twofold diluted. LOD: limit of detection; EF: enrichment factor.

obtained from $b+3 s ; b$ is the mean concentration of 10 consecutive measurements of the sample blank and $\mathrm{s}$ is the standard deviation. The blank solution (of sample analysis or calibration curve) was subjected to the same preconcentration procedure that samples and calibration solutions. Contamination problems were not found for $\mathrm{Se}$, and the same was observed for $\mathrm{Sb}$.

EF was calculated by the ratio of the slopes of calibration curves (with and without analyte preconcentration) for each system used for introducing the surfactant-rich phase into the ICP. As expected and in accordance with the slopes of the calibration curves, the worst sensitivity was observed when PN was used. However, when Se(IV) was preconcentrated using $\mathrm{CPE}$, the sensitivity was 44 times better and the enrichment factor was 40 . For both $\mathrm{HG}$ and PN, LOD of Se(IV) was almost 10 times better when the species was preconcentrated using CPE.

Pneumatic nebulization/aerosol desolvation was also investigated for Se(IV), but any signal of Se was also observed. The difficulty of measuring Se through the nebulization/aerosol desolvation system employed was observed by other authors. ${ }^{21}$ It is possible that Se is volatilized in the heating step in the desolvation system, or the mechanisms of energy transfer for Se in the ICP are modified when a desolvated aerosol is introduced into the ICP.

$\mathrm{Se}(\mathrm{IV})$ complexes with DDTP while Se(VI) does not. ${ }^{22}$ Aiming total selenium determination as well as Se(IV) and $\mathrm{Se}(\mathrm{VI})$, the reduction of $\mathrm{Se}(\mathrm{VI})$ to $\mathrm{Se}(\mathrm{IV})$ was investigated. The usual procedure consists of heating the $\mathrm{Se}(\mathrm{VI})$ solution in $6 \mathrm{~mol} \mathrm{~L}^{-1} \mathrm{HCl}$ for $30 \mathrm{~min}$ at $100^{\circ} \mathrm{C}$. In the present study, the influence of $\mathrm{HCl}$ concentration was evaluated in order to use less concentrated $\mathrm{HCl}$ solution as possible (according to Figure 1a). As it can be seen in Figure 2, for effective reduction of $\mathrm{Se}(\mathrm{VI})$, the $\mathrm{HCl}$ concentration should be at least $5.0 \mathrm{~mol} \mathrm{~L}^{-1}$, which is consistent with the literature..$^{23}$

Selenium in the non-lipid fraction of Brazil nut sample was initially quantified. The analyte was determined directly in the sample solution (not submitted to CPE) using HG-ICP OES (hydride generation-inductively coupled

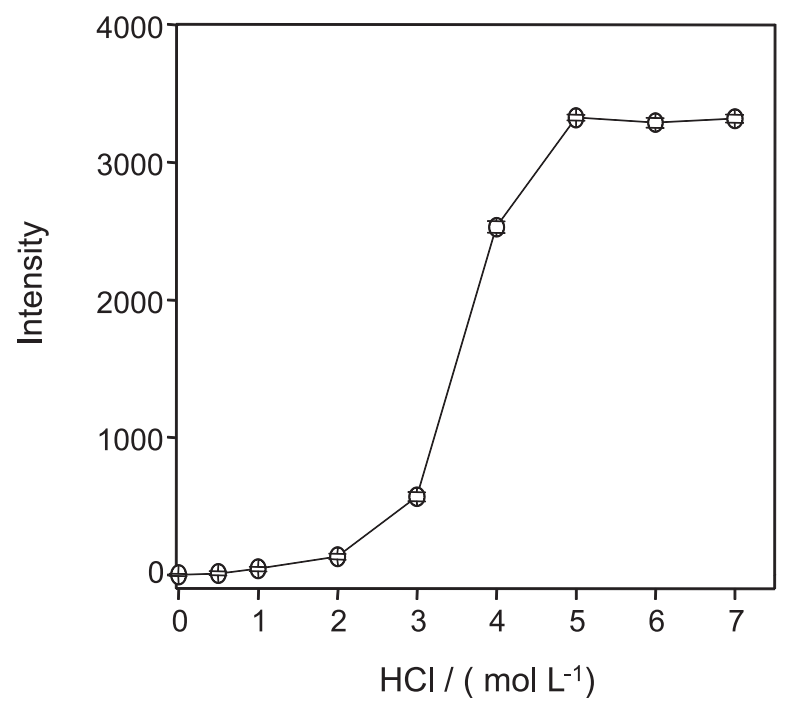

Figure 2. Effect of $\mathrm{HCl}$ concentration in reducing $\mathrm{Se}(\mathrm{VI})$ to $\mathrm{Se}(\mathrm{IV})$ [25 $\left.\mathrm{mg} \mathrm{L}^{-1} \mathrm{Se}(\mathrm{VI})\right]$.

plasma optical emission spectrometry). Selenium recovery in the sample solution submitted or not to the reduction procedure (using $5 \mathrm{~mol} \mathrm{~L}^{-1} \mathrm{HCl}$ and heating at $100^{\circ} \mathrm{C}$ ) was similar as can be seen in Table 5 . Thus, it was concluded that $\mathrm{Se}(\mathrm{VI})$ is not present in Brazil nut since the concentration of $\mathrm{Se}$ (IV) did not increase when the sample solution was submitted to the reduction procedure. In Table 5, one can observe that the recovery of Se in the certified sample DOLT-4 is quantitative, indicating the accuracy of the HG-ICP OES method.

The extract of the Brazil nut sample was also decomposed in microwave oven (see procedure 2 in the Experimental section). The Se(IV) concentrations found for both decomposition procedures (1 and 2) were similar (see Table 5) at 99\% confidence level. Then, procedure 1 was selected and employed for decomposition of all analyzed solid samples.

After reduction of $\mathrm{Se}(\mathrm{VI})$ and respective dilution, the final concentration of $\mathrm{HCl}$ in the solution submitted to $\mathrm{CPE}$ was about $0.6 \mathrm{~mol} \mathrm{~L}^{-1}$. By adding DDTP to this solution, a white precipitate was produced. It was initially supposed that 
Table 5. Selenium concentration found in non-lipid fraction of Brazil nut and certified dogfish liver (DOLT-4); HG-ICP OES (hydride generation-inductively coupled plasma optical emission spectrometry) was employed for Se(IV) determination

\begin{tabular}{|c|c|c|c|}
\hline Brazil Nut & Spiked/ $\left(\mu \mathrm{g} \mathrm{g}^{-1}\right)$ & Found $/\left(\mu \mathrm{g} \mathrm{g}^{-1}\right)$ & Recovery/(\%) \\
\hline \multirow{5}{*}{ Reduction of $\mathrm{Se}(\mathrm{VI})^{\mathrm{a}}$} & - & $48.9 \pm 1.7^{b}$ & - \\
\hline & & $49.2 \pm 1.5^{\mathrm{c}}$ & \\
\hline & $25.0 \mathrm{Se}(\mathrm{IV})$ & $72.0 \pm 0.5$ & 92 \\
\hline & $25.0 \mathrm{Se}(\mathrm{VI})$ & $72.3 \pm 3.2$ & 91 \\
\hline & - & $49.6 \pm 0.2$ & \\
\hline Without reduction of $\mathrm{Se}(\mathrm{VI})$ & $25.0 \mathrm{Se}(\mathrm{IV})$ & $72.2 \pm 0.2$ & 90 \\
\hline DOLT-4 & Certified $/\left(\mu \mathrm{g} \mathrm{g}^{-1}\right)$ & Found $/\left(\mu \mathrm{g} \mathrm{g}^{-1}\right)$ & Recovery/(\%) \\
\hline Reduction of $\mathrm{Se}(\mathrm{VI})^{\mathrm{a}, \mathrm{c}}$ & $8.3 \pm 1.3$ & $8.7 \pm 1.2$ & 104 \\
\hline
\end{tabular}

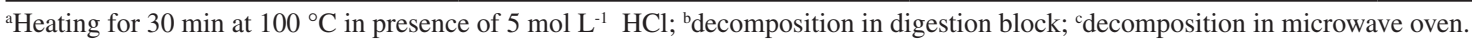

the acid medium induced the formation of this precipitate, possible products originated from DDTP degradation. However, any precipitate was not observed in Se(IV) solution directly prepared in $5 \mathrm{~mol} \mathrm{~L}^{-1} \mathrm{HCl}$ not submitted to heating. It was concluded that interfering species are formed during heating for reduction of $\mathrm{Se}(\mathrm{VI})$ in presence of $\mathrm{HCl}$. Thus, the reduction of $\mathrm{Se}(\mathrm{VI})$ was attempted by using L-cysteine. In this case, PN was employed because L-cysteine produces Se species that are not reactive in the HG system. The reduction of $\mathrm{Se}(\mathrm{VI})$ was carried out according to the procedure described by Li et al. ${ }^{7}$ (with L-cysteine $0.5 \%(\mathrm{~m} / \mathrm{v}$ ) and heating at $100{ }^{\circ} \mathrm{C}$ for $25 \mathrm{~min}$ ). Subsequently, the solution was submitted to CPE. However, the emission signal of Se remained at the background level, indicating that $\mathrm{Se}(\mathrm{VI})$ was not reduced by L-cysteine, or the L-cysteine may interfere in the complexation of $\mathrm{Se}(\mathrm{IV})$ and/or cloud point extraction. Therefore, only Se(IV) can be determined when DDTP is used for CPE.

Aliquots of the nut sample solutions were submitted to CPE for preconcentration of Se(IV) present, which was measured using HG-ICP OES. Selenium(IV) was detected in Brazil nut, but the concentration found was $70 \%$ lower

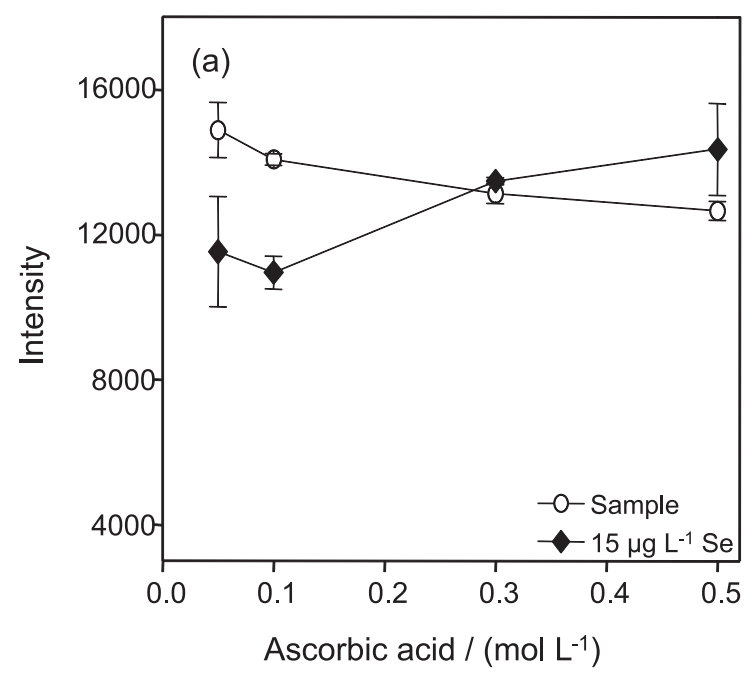

than that shown in Table 5, by direct determination (without CPE).

It is known that $\mathrm{Fe}(\mathrm{III})$ complexes with DDTP and it is a potential interfering. Possible interference by $\mathrm{Fe}(\mathrm{III})$ was investigated by adding ascorbic acid to aliquots of the Brazil nut solution in order to reduce $\mathrm{Fe}$ (III) to $\mathrm{Fe}$ (II) that does not form a complex with DDTP. However, according to Figure 3a, quite similar profiles are observed for Se(IV) in the solution of the Brazil nut sample and in the Se(IV) solution test. Excess of DDTP could also be a source of interference because DDTP competes with Se-DDTP for the micelle sites. According to Figure 3b, the same behavior is observed for $\mathrm{Se}(\mathrm{IV})$ in the solution of the Brazil nut and in the $\mathrm{Se}(\mathrm{IV})$ solution tested. According to these results, it is supposed that interference probably occurs at the stage of hydride generation of Se(IV) in the surfactant rich phase of the Brazil nut extract.

\section{Selenium determination in samples}

Taking into account the low recovery of Se(IV) in Brazil nut, $\mathrm{Se}(\mathrm{IV})$ in the nut samples was quantified using PN

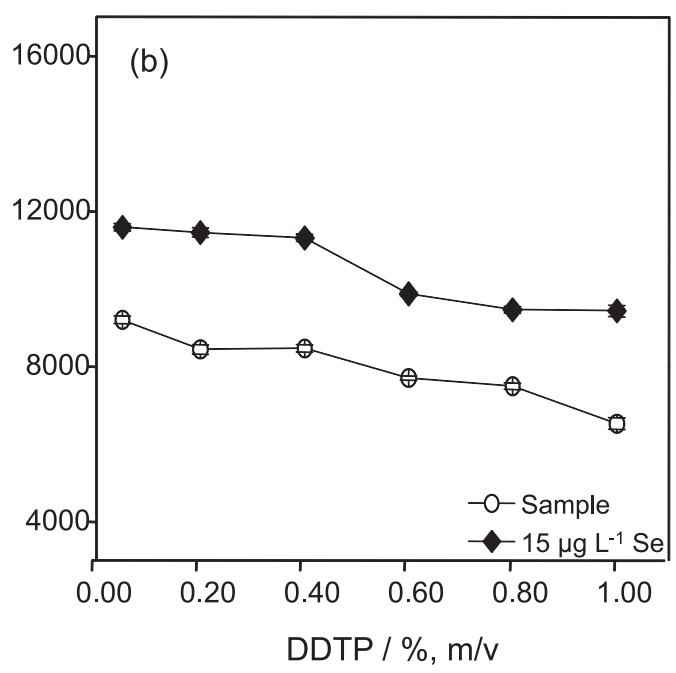

Figure 3. Influence of ascorbic acid and DDTP on preconcentration of Se(IV) in Brazil nut and in solution containing Se(IV) and $50 \mathrm{mg} \mathrm{L} \mathrm{L}^{-1}$ of Fe (III); $\mathrm{n}=3$. 
for introducing the surfactant rich phase in the ICP. The concentration of Se(IV) found in the samples is shown in Table 6. The Se(IV) concentration in the nuts is expressed for the non-lipid fraction in which Se is present in the nuts, corresponding to $60 \%$ of weight of raw nuts. ${ }^{11}$ Hence, the concentration of $\mathrm{Se}(\mathrm{IV})$ in the raw Brazil nut is about $30 \mu \mathrm{g} \mathrm{g}^{-1}$. Considering that a daily intake of 50-70 $\mu \mathrm{g}$ of Se is recommended, ${ }^{1}$ the quantity of Se in the human body is supplied just by eating $2 \mathrm{~g}$ Brazil nut per day. The proteins found in Brazil nut are very high in sulfur-containing amino acids like cysteine and methionine and are also extremely rich in glutamine, glutamic acid and arginine. ${ }^{24}$ The reason that Brazil nut concentrate Se is probably that this element is very similar chemically to S. Sulfur is frequently deficient in Amazonian soils. Thereby, Se may be used by the plant instead of $\mathrm{S}$.

Selenium was not detected in coconut water. Other authors ${ }^{25}$ detected Se in this beverage, differently of the results obtained in the present study. The reason might be the type of soil where the coconut plant is grown. The analyzed coconut water sample is from region probably poor in Se.

\section{Antimony}

The influence of the preconcentration medium was evaluated using $\mathrm{HCl}$ at different concentrations, the analyte was measured using HG-ICP OES. The highest $\mathrm{Sb}$ (III) signal was observed for $0.80 \mathrm{~mol} \mathrm{~L}^{-1} \mathrm{HCl}$, as shown in Figure 4a. It is already known ${ }^{22}$ that DDTP forms stable complexes with $\mathrm{Sb}$ (III). The influence of the DDTP concentration was also evaluated and the results are
Table 6. Concentration of Se(IV) found in the analyzed samples. Results are the mean and standard deviation of three determinations (analysis in triplicate). Pneumatic nebulization (PN) was used to introduce the surfactant-rich phase into the ICP. Se(IV) concentration in the nuts is expressed in the non-lipid fraction

\begin{tabular}{lccc}
\hline Sample & Spiked / $\left(\mu \mathrm{g} \mathrm{g}^{-1}\right)$ & Found / $\left(\mu \mathrm{g} \mathrm{g}^{-1}\right)$ & Recovery / \% \\
\hline Brazil nut & - & $50.8 \pm 1.8$ & \\
\hline Sweet almond & 34.9 & $86.9 \pm 0.2$ & 103 \\
\hline Walnut & - & $<0.90$ & \\
& 6.99 & $6.39 \pm 1.17$ & 91 \\
\hline Hazelnut & - & $<0.90$ & \\
\hline Sample & 6.99 & $6.11 \pm 0.42$ & 87 \\
\hline Coconut water & - & $<0.90$ & 90 \\
\hline Spiked / $\left(\mu \mathrm{g} \mathrm{g} \mathrm{g}^{-1}\right)$ & Found / $\left(\mu \mathrm{g} \mathrm{g}^{-1}\right)$ & $\mathrm{Recovery} \mathrm{/ \%}$ \\
\hline & - & $<1.80$ & \\
& 10 & $8.52 \pm 0.84$ & 85 \\
& 5 & $5.12 \pm 0.34^{\mathrm{a}}$ & 102 \\
\hline
\end{tabular}

${ }^{\mathrm{a}}$ Quantified using CPE and HG-ICP OES.

shown in Figure 4b. It can be observed that the signal of $\mathrm{Sb}$ increases with the DDTP concentration increasing up to $0.40 \%(\mathrm{~m} / \mathrm{v})$, decreasing thereafter. Since the increasing of the Sb signal was low for 0.20 to $0.40 \%(\mathrm{~m} / \mathrm{v})$ DDTP, the concentration of the complexant was fixed in $0.2 \%(\mathrm{~m} / \mathrm{v})$ for further $\mathrm{Sb}$ (III) determinations. Souza et al., ${ }^{26}$ using multivariate optimization, found quite similar results. These authors observed that $0.15 \%(\mathrm{~m} / \mathrm{v})$ DDTP was optimal for preconcentration of $\mathrm{Sb}$ (III) in blood serum by means of $\mathrm{CPE}$ prior to $\mathrm{Sb}$ detection using ETAAS.
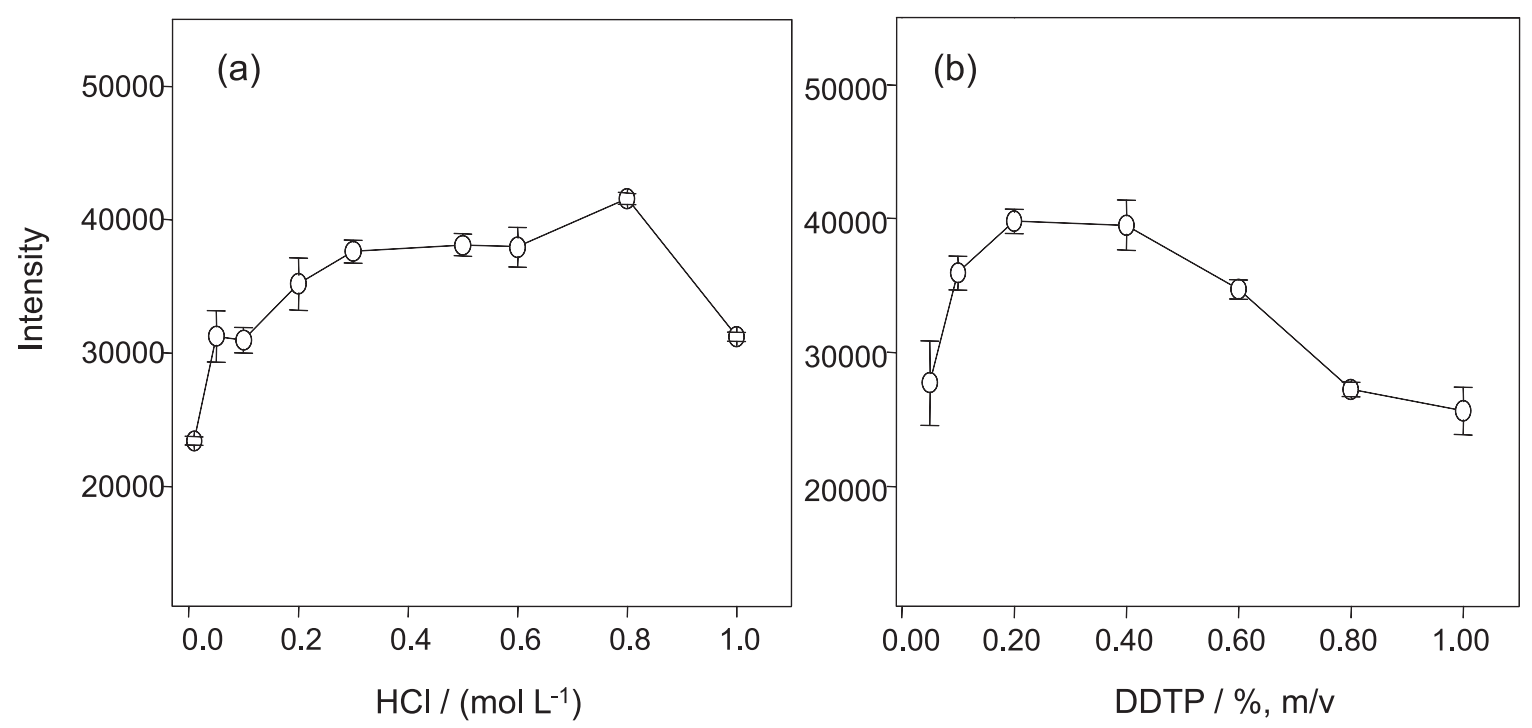

Figure 4. Influence of $\mathrm{HCl}$ and DDTP on preconcentration of $\mathrm{Sb}(\mathrm{III})$ using CPE; HG-ICP OES was used for Sb(III) determination; test solution: $10.0 \mu \mathrm{g} \mathrm{L}^{-1}$

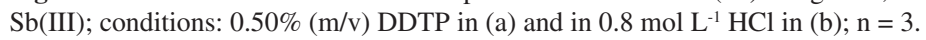



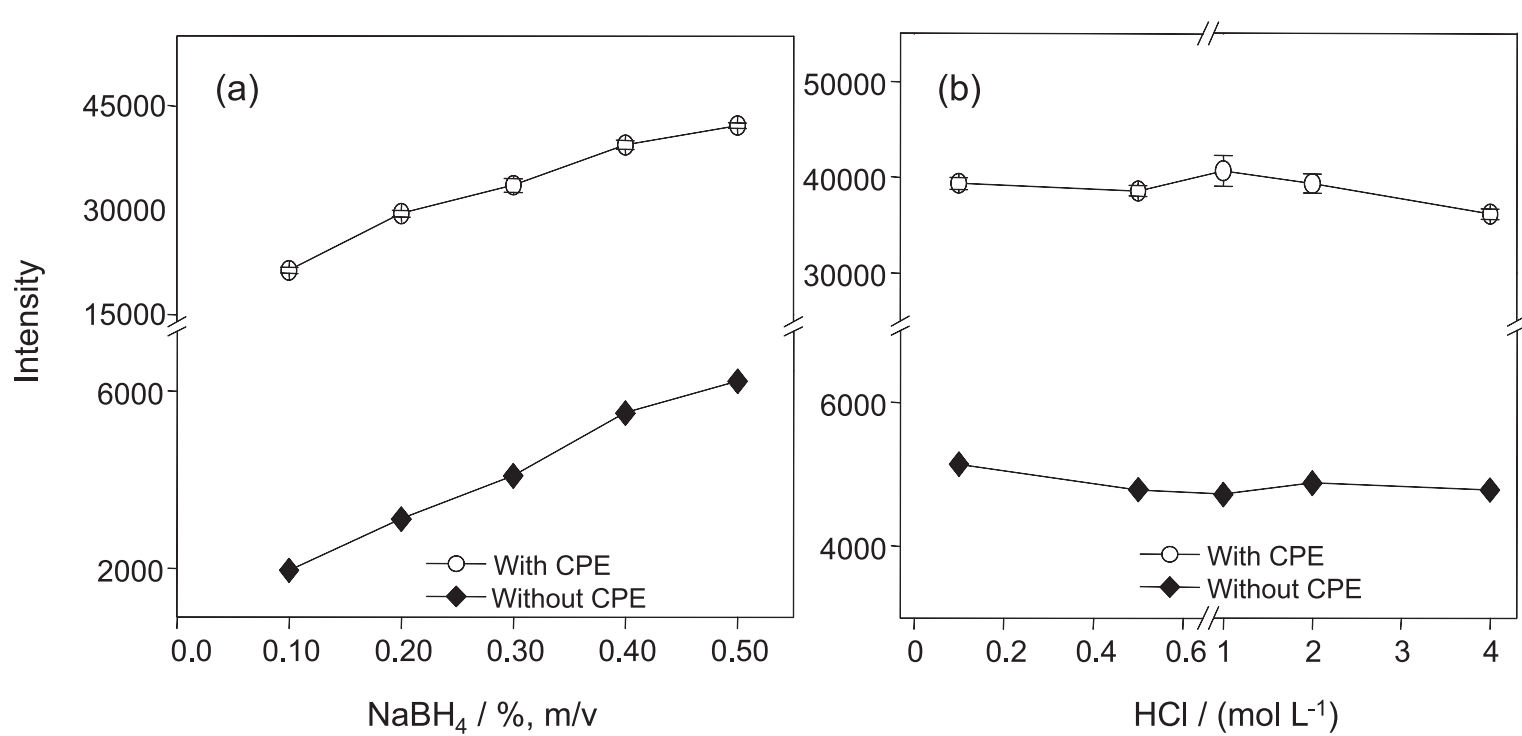

Figure 5. Influence of $\mathrm{NaBH}_{4}$ and $\mathrm{HCl}$ concentrations on $\mathrm{Sb}$ (III) hydride generation. A $10.0 \mu \mathrm{g} \mathrm{L}^{-1} \mathrm{Sb}$ (III) solution was used. Conditions: 0.80 mol L ${ }^{-1}$ $\mathrm{HCl}$ in (a) and $0.20 \%(\mathrm{~m} / \mathrm{v})$ DDTP in (b); $\mathrm{n}=3$.

Regarding to Triton X-114 concentration, the highest $\mathrm{Sb}$ signal was observed when the surfactant concentration was $0.10 \%(\mathrm{~m} / \mathrm{v})$. The volume of methanol added to the surfactant-rich phase was $100 \mu \mathrm{L}$, following what was observed for Se.

With respect to $\mathrm{NaBH}_{4}$ and $\mathrm{HCl}$ solutions used in the HG system, it was observed that the Sb signal increased with the $\mathrm{NaBH}_{4}$ concentration increase (Figure 5a), but remained almost constant with $\mathrm{HCl}$ concentration increasing up to $2 \mathrm{~mol} \mathrm{~L}^{-1}$ (Figure 5b). However, elevated effervescence was observed in the gas-liquid separator by using $0.50 \%(\mathrm{~m} / \mathrm{v}) \mathrm{NaBH}_{4}$, which could lead to inaccurate results. Thus, the $\mathrm{NaBH}_{4}$ concentration was reduced to $0.40 \%(\mathrm{~m} / \mathrm{v})$, without great loss of sensitivity. The $\mathrm{HCl}$ concentration selected was $0.8 \mathrm{~mol} \mathrm{~L}^{-1}$. The conditions established for $\mathrm{Sb}$ (III) preconcentration/determination as well as those for Se(IV) are summarized in Table 7.

Table 7. Condition and reagent concentration established for $\mathrm{Sb}$ and $\mathrm{Se}$ preconcentration using $\mathrm{CPE}$

\begin{tabular}{|c|c|c|}
\hline \multirow{2}{*}{ Condition/Reagent } & \multicolumn{2}{|c|}{ Element } \\
\hline & $\mathrm{Sb}$ & $\mathrm{Se}$ \\
\hline Preconcentration medium, $\mathrm{HCl} /\left(\mathrm{mol} \mathrm{L}^{-1}\right)$ & 0.8 & 0.1 \\
\hline $\mathrm{DDTP} / \%, \mathrm{~m} / \mathrm{v}$ & 0.20 & 0.05 \\
\hline Triton X-114 / \%, m/v & 0.10 & 0.20 \\
\hline Temperature $/{ }^{\circ} \mathrm{C}$ & 50 & 50 \\
\hline Heating time / $\min$ & 20 & 20 \\
\hline $\mathrm{HCl}$ for $\mathrm{HG} /\left(\mathrm{mol} \mathrm{L}^{-1}\right)$ & 1 & 0.1 \\
\hline $\mathrm{NaBH}_{4} / \%, \mathrm{~m} / \mathrm{v}$ & 0.40 & 0.50 \\
\hline
\end{tabular}

Figures of merit

LOD of $\mathrm{Sb}(\mathrm{III}), \mathrm{EF}$ and parameters of calibration curves obtained by using CPE for preconcentration followed by determination using HG-ICP OES or PN-ICP OES (pneumatic nebulization-inductively coupled plasma optical emission spectrometry) are summarized in Table 8. LOD and EF were calculated in the same way that selenium, as previously described.

The LOD obtained for $\mathrm{Sb}$ (III) using HG-ICP OES is similar to that reported by Li et al.. ${ }^{14}$ By using APDC and Triton X-114 for preconcentration of Sb prior to its determination using ETV-ICP OES, these authors found a LOD of $0.09 \mu \mathrm{g} \mathrm{L}^{-1}$ for $\mathrm{Sb}$ (III).

In the present work, it was observed that aerosol desolvation enhanced sensitivity for $\mathrm{Sb}$, but LOD was worst $\left(5.50 \mu \mathrm{g} \mathrm{L}^{-1}\right)$ when compared with that obtained using conventional nebulization $\left(2.90 \mu \mathrm{g} \mathrm{L}^{-1}\right)$. The main reason for the higher LOD is that precision was worsened by using pneumatic nebulization/aerosol desolvation for introducing the viscous surfactant-rich phase into the ICP.

\section{Antimony determination in samples}

After evaluating the appropriate conditions for $\mathrm{Sb}$ (III) preconcentration using $\mathrm{CPE}$, this specie was determined in different samples, as shown in Table 9. Antimony(III) was not detected in tap water and white wine, but was in estuarine water, seawater and mineral water. The samples were spiked with $\mathrm{Sb}$ (III) and recoveries varied from 87 to $106 \%$, demonstrating that relatively low concentrations of $\mathrm{Sb}$ (III) can be determined using CPE and HG-ICP OES. 
Table 8. Comparison of pneumatic nebulization (PN) and hydride generation (HG) performances for Sb(III) determination using ICP OES after preconcentration by $\mathrm{CPE}$

\begin{tabular}{|c|c|c|c|c|}
\hline $\begin{array}{l}\text { Sample introduction } \\
\text { system }\end{array}$ & $\begin{array}{l}\text { Slope of calibration } \\
\text { curve }\end{array}$ & $\mathrm{EF}$ & $\mathrm{LOD} /\left(\mu \mathrm{g} \mathrm{L}^{-1}\right)$ & $\begin{array}{l}\text { Linear correlation coefficient of } \\
\text { calibration curve }\end{array}$ \\
\hline HG (with CPE) & 1817 & 5 & 0.080 & 0.9994 \\
\hline HG (without CPE) & 363 & - & 1.1 & 0.9990 \\
\hline $\mathrm{PN}$ & 27.2 & 7 & 2.90 & 0.9970 \\
\hline PN (without CPE) & 3.02 & - & 12 & 0.9980 \\
\hline $\mathrm{PN} / \mathrm{DES} / \mathrm{CPE}$ & 54.7 & 32 & 5.50 & 0.9890 \\
\hline
\end{tabular}

LOD: limit of detection; EF: enrichment factor; PN/DES/CPE: pneumatic nebulization/aerosol desolvation/cloud point extraction.

The certified river water (SLRS-5) was submitted to $\mathrm{CPE}$ and the recovery of total $\mathrm{Sb}$ was $90 \%$. However, the concentration of $\mathrm{Sb}$ is not certified, but only informed. It is important to mention the lack of reference materials in which the concentrations of Sb species are certified. The same is true for Se. Only for As, $\mathrm{Sn}$ and $\mathrm{Hg}$ are found reference materials where some species of these elements are certified.

Table 9. Samples analysis using CPE and HG-ICP OES for Sb(III) quantification. Results are the mean and standard deviation $(n=3)$

\begin{tabular}{lccc}
\hline Sample & $\begin{array}{c}\text { Spiked / } \\
\left(\mu \mathrm{g} \mathrm{L}^{-1}\right)\end{array}$ & $\begin{array}{c}\text { Found / } \\
\left(\mu \mathrm{g} \mathrm{L}^{-1}\right)\end{array}$ & $\begin{array}{c}\text { Recovery / } \\
\%\end{array}$ \\
\hline Estuarine water & - & $2.90 \pm 0.54$ & \\
\hline Seawater & 2.5 & $5.54 \pm 0.21$ & 106 \\
\hline Mineral water & - & $0.79 \pm 0.07$ & \\
\hline Tap water & 2.5 & $2.96 \pm 0.02$ & 87 \\
\hline White wine & - & $0.39 \pm 0.09$ & \\
\hline River water (SLRS-5) & 2.5 & $2.66 \pm 0.19$ & 91 \\
\hline
\end{tabular}

${ }^{a}$ LOD (limit of detection) calculated for the sample 10-fold diluted; binformed value (sample not spiked with $\mathrm{Sb}(\mathrm{III})$ ).

Antimony (III) is very toxic. However, Sb(III) was detected in some samples. Antimony has been investigated in European mineral waters stored in PET bottles. In the present work, the concentration of $\mathrm{Sb}$ (III) found in bottled mineral water compares well with the average $\mathrm{Sb}$ concentration found in mineral water from Europe. ${ }^{27}$

Hydride generation efficiency of an element depends on whether the element is present as an inorganic or organic form and on its oxidation state. As only the $\mathrm{Sb}$ (III) species of the element are efficiently reduced to $\mathrm{SbH}_{3}$, a pre reducing agent is often used to convert $\mathrm{Sb}(\mathrm{V})$ to $\mathrm{Sb}(\mathrm{III})$ prior to hydride generation. Besides, the complexant (DDTP) used for CPE in the present study does not complex with $\mathrm{Sb}(\mathrm{V})$. Thus, when attempting to determine $\mathrm{Sb}(\mathrm{V})$ using DDTP and/or hydride generation a pre-reduction step is needed. Potassium iodide and ascorbic acid or L-cysteine were used for $\mathrm{Sb}(\mathrm{V})$ reduction. ${ }^{28}$

A study was conducted following the conditions described in the literature ${ }^{21}$ for reducing $\mathrm{Sb}(\mathrm{V})$. For this, potassium iodide $1 \%(\mathrm{~m} / \mathrm{v})$ and ascorbic acid $0.2 \%$ $(\mathrm{m} / \mathrm{v})$ were left in contact with the sample solution for $30 \mathrm{~min}$. Conversion of $\mathrm{Sb}(\mathrm{V})$ to $\mathrm{Sb}(\mathrm{III})$ was considered satisfactory (reduction of about $80 \%$ ). Aliquots of the samples were subsequently submitted to CPE, but the concentrations of $\mathrm{Sb}$ (III) found were similar to those shown in Table 8. Consequently, the concentrations of the $\mathrm{Sb}(\mathrm{V})$ in the samples were lower than the LOD of the method (0.08 $\mu \mathrm{g} \mathrm{L}^{-1}$ for water samples and $0.4 \mu \mathrm{g} \mathrm{\textrm {L } ^ { - 1 }}$ for wine).

\section{Conclusions}

It was here demonstrated that $\mathrm{CPE}$ in conjunction with HG improved LODs of $\mathrm{Sb}$ and $\mathrm{Se}$, allowing the determination of low concentrations of $\mathrm{Se}$ (IV) and $\mathrm{Sb}$ (III) by ICP OES with axial view of the plasma. However, CPE of $\mathrm{Se}(\mathrm{IV})$ in solution of $\mathrm{HCl}$ previously heated in order to reduce $\mathrm{Se}(\mathrm{IV})$ was not possible. As a consequence, only $\mathrm{Se}(\mathrm{IV})$ could be quantified since DDTP complexes only with $\mathrm{Se}(\mathrm{IV})$. In this case, speciation of $\mathrm{Se}(\mathrm{IV})$ at $\mathrm{ng} \mathrm{L}^{-1}$ level was possible. Selenium(IV) could not be quantified in Brazil nut using CPE and $\mathrm{HG}$ due to possible interferences in the hydride generation stage. However, $\mathrm{Se}(\mathrm{IV})$ in this sample could be quantified by using CPE and PN. Only $\mathrm{Se}(\mathrm{IV})$ was detected in Brazil nut sample submitted to treatment in which $\mathrm{Se}(\mathrm{VI})$ was not detected.

Selenium could not be measured by using nebulization/ aerosol desolvation, contrarily of Sb. However, LOD of Sb was higher than that found using PN. LOD found for Sb, using HG and CPE followed by detection by ICP OES, 
revealed that the technique is appropriate for Sb monitoring in environmental samples. Antimony(III), the most toxic inorganic Sb species, was detected in estuarine water, seawater and in mineral water stored in PET bottle.

\section{Acknowledgements}

F. S. Depoi would like to thank the Coordenação de Aperfeiçoamento de Pessoal de Nível Superior (CAPES) for the scholarship provided.

\section{References}

1. Högberg, J.; Alexander, J.; Handbook on the Toxicology of Metals, $3^{\text {rd }}$ ed.: Elsevier: Amsterdam, The Netherlands, 2007, ch. 38 .

2. Hansen, C.; Tsirigotaki, A.; Alex, B. S.; Pergantis, S. A.; Stürup, S.; Gammelgaard, B.; Hansen, H. R.; J. Environ. Monit. 2010, 12, 822 .

3. Carrión, N.; Murillo, M.; Montieli, E.; Diáz, D.; Spectrochim. Acta, Part B 2003, 58, 1375 .

4. Güler, N.; Maden, M.; Bakırdere, S.; Yavuz Ataman, O.; Volkan, M; Food Chem. 2011, 129, 1793.

5. Kolachi, N. F.; Kazi, T.; Wadhwa, S. K.; Afridi, H. I.; Baig, J. A.; Khan, S.; Shah, F.; Sci. Total Environ. 2011, 409, 3092.

6. Beibei, C.; Hu, B.; He, M.; Rapid Commun. Mass Spectrom. 2006, 20, 2894.

7. Li,Y.; Hu, B.; He, M; Xiang, G.; Water Res. 2008, 42, 1195.

8. Sounderajan, S.; Kumar, G. K.; Udas, A. C.; J. Hazard. Mater. 2010, 175, 666 .

9. Ghambarian, M.; Yamini, Y.; Saleh, A.; Shariati, S.; Yazdanfar, N.; Talanta 2009, 78, 970.

10. Jiang, X.; Wen, S.; Xiang, G.; J. Hazard. Mater. 2010, 175, 46.

11. Samadi-Maybodi, A.; Rezaei, V.; Microchim. Acta 2012, 178, 399.
12. Hagarova, I.; Bujdos, M.; Matus, P.; Chemicke Listy 2012, 106, 136.

13. Fan, Z.; Microchim. Acta 2005, 152, 29.

14. Li, Y.; Hu, B.; Jiang, Z.; Anal. Chim. Acta 2006, 576, 207.

15. Hagarova, I.; Kubova, J.; Matus, P.; Bujdos, M.; Acta Chim. Slov. 2008, 55, 528.

16. Depoi, F. S.; Bentlin, F. R. S.; Pozebon, D.; Anal. Methods 2010, 2, 180.

17. Depoi, F. S.; de Oliveira Charão, T.; Pompéu, D. de M.; Pozebon, D.; Anal. Methods 2012, 4, 89.

18. Welna, M.; Klimpel, M.; Zyrnicki, W.; Food Chem. 2008, 111, 1012.

19. Hinze, W. L.; Pramauro, E.; Crit. Rev. Anal. Chem. 1993, 24, 133.

20. Dressler, V. L.; Pozebon, D.; Curtius, J. A.; Spectrochim. Acta, Part B 1998, 53, 1527.

21. D’llio, S.; Violante, N.; Caimi, S.; di Gregorio, M.; Petrucci, F.; Senofone, O.; Anal. Chim. Acta 2006, 574, 432.

22. Bode, H.; Arnwald, W.; Fresenius J. Anal. Chem. 1962, 185, 179.

23. Meyers, R. A.; Encyclopedia of Analytical Chemistry; Wiley: Chichester, UK, 2010, p. 945.

24. Dumont, E.; De Pauw, L.; Vanhaecke, F.; Cornelis, R.; Food Chem. 2006, 95, 684.

25. Oliveira, A. P.; Gomes Neto, J. A.; Nóbrega, J. A.; Correia, P. R. M.; Oliveira, P. V.; Food Chem. 2005, 93, 355.

26. Souza, J. M. O.; Tarley, C. R. T.; Anal. Lett. 2008, 41, 2465.

27. Keresztes, S.; Tatár, E.; Mihucz, G. V.; Virág, I.; Majdik, C.; Záray, G.; Sci. Total Environ. 2009, 407, 4731.

Submitted: September 15, 2012 Published online: January 9, 2013 